\title{
Penerapan Konseling Kelompok Dalam Aspek Kompetensi Intrapersonal Siswa Kelas X
}

\author{
Sri Mulyati ${ }^{1}$, Iip Istirahayu ${ }^{2)}$ \\ 1) Prodi Bimbingan dan Konseling STKIP Singkawang \\ e-mail: mulyatissri957@gmail.com \\ 2) Prodi Bimbingan dan Konseling STKIP Singkawang \\ e-mail:iip_istirahayu@yahoo.com
}

\begin{abstract}
Abstrak. Penelitian ini bertujuan untuk memperoleh gambaran pelaksanaan layanan konseling kelompok dalam meningkatkan kompetensi intrapersonal siswa kelas X disalah satu SMA Negeri di Kota Singkawang. Pengambilan sampel dalam penelitian ini adalah random cluster sampling. Instrumen pengumpulan data menggunaakan RPL (Rancangan Pelaksanaan Layanan). Analisis data menggunakan teknik analisis deskriptif. Hasil penelitian menunjukkan bahwa siswa yang diberikan perlakuan sebanyak tiga kali pertemuan dengan 4 tahap konseling, yang mana tahap demi tahap siswa mulai menunjukkan sikap percaya diri, mampu untuk memahami diri, menyadari kelemahan dan kelebihan, mampu membuat keputusan, mampu menghadapi kegagalan, disiplin diri, mampu mengendalikan diri, menghargai diri, dan menerima diri sebagai orang yang berharga.
\end{abstract}

Kata Kunci : Identifikasi, Kompetensi Intrapersonal.

\section{Pendahuluan}

Kompetensi intrapersonal adalah kemampuan yang membantu orang berhubungan baik dengan diri sendiri belajar. Tujuan dari kompetensi intrapersonal adalah untuk meningkatkan kuantitas dan kualitas kebutuhan pemenuhan seseorang [1]. Hubungan intrapersonal berurusan dengan tiga kompetensi: pengetahuan diri, pengarahan diri sendiri, dan harga diri [1].

Kompetensi intrapersonal adalah individu kompetensi pria dan wanita yang mampu berhubungan baik dengan diri [5]. Kompetensi intrapersonal penting bagi semua orang karena dengan kecerdasan ini seseorang mampu menempuh keberhasilan dan kesuksesannya sendiri. Beberapa alasan mengapa kompetensi intrapersonal itu penting, antara lain :1) Stabilitas emosional, Dengan stabilitas emosional seseorang dapat menyeimbangkan antara kekuatan diri dan harapan yang akan dicapai; 2) Meningkatkan motivasi diri, Dengan motivasi ini seseorang akan mampu mengendalikan emosi, sehingga kesadaran logisnya yang digunakan untuk bertindak; 3) Menumbuhkan rasa tanggung jawab; 4) Mengembangkan harga diri, Harga diri yang dimaksud adalah kesadaran akan diri tentang seberapa jauh seseorang dicintai, dihargai, dan dihormati orang lain.

Konseling kelompok membantu siswa untuk mampu mengelola dirinya. Artinya, siswa dituntut untuk mampu berhubungan secara baik dengan dirinya dalam memahami, mengarahkan, dan menghargai dirinya sebagai individu yang memiliki kemampuan untuk mengembangkan potensi dan menyelesaikan persoalan yang ada.

Profesi bimbingan dan konseling merupakan pekerjaan yang langsung berhubungan dengan individu yang beragam secara pribadi, sosial dan latar belakang kehidupannya. Guru bimbingan dan konseling akan berhadapan dengan individu yang sedang menjalani tahap perkembangan tertentu dengan tugas-tugas perkembangan yang harus diselesaikannya, sehingga dalam hal ini peran konselor dalam kegiatan bimbingan dan konseling merupakan aspek yang sangat penting untuk diperhatikan.

Upaya yang dapat dilakukan oleh guru Bimbingan dan Konseling di sekolah adalah terkait dengan kompetensi intrapersonalnya untuk membantu konseli memahami kekurangan dan kelebihan yang dimiliki dirinya, mengarahkan dirinya agar mampu mengarahkan kehidupannya dan menerima dirinya sebagai orang yang berharga.

Beberapa penelitian menjelaskan bahwa kompetensi intrapersonal merupakan satu dimensi daya psikologi yang memiliki posisi strategis dalam mempengaruhi berkembangnya dua dimensi daya psikologi lainnya yaitu kompetensi interpersonal dan pemenuhan kebutuhan. Terbangunnya kekuatan intrapersonal pada diri siswa, akan memudahkannya dalam menyadari kebutuhannya sehingga bisa menjadi wahana dalam memenuhi kebutuhannya. 


\section{Metode Penelitian}

Jenis penelitian yang digunakan adalah penelitian kualitatif untuk mengetahui gambaran pelaksanaan layanan konseling.

\section{Hasil dan Pembahasan}

Pelaksanaan layanan konseling kelompok yang dilaksanakan oleh peneliti disalah satu SMA Negeri di Kota Singkawang. Dari pelaksanaan konseling kelompok peneliti dapat melihat perkembangan siswa yang diberikan perlakuan sebanyak tiga kali pertemuan yang mana tahap demi tahap siswa mulai menunjukkan sikap percaya diri, mampu untuk memahami diri, menyadari kelemahan dan kelebihan, mampu membuat keputusan, mampu menghadapi kegagalan, disiplin diri, mampu mengendalikan diri, menghargai diri, dan menerima diri sebagai orang yang berharga.

Treatment diberikan dengan memberikan layanan secara berkelanjutan menggunakan konseling kelompok dengan 4 tahapan yaitu tahap permulaan, tahap peralihan, tahap kegiatan dan tahap pengakhiran, [9]. Sesuai dengan jadwal yang disepakati peneliti dengan siswa yaitu hari Selasa kegiatan treatment dilaksanakan 3 kali pertemuan yaitu mulai 09 Febuari 2016, 13 Febuari 2016 dan tanggal 18 Febuari 2016. Layanan ini akan berhasil apabila siswa menunjukkan sikap memahami dirinya, mampu mengarahkan dirinya dan mampu menghargai dirinya.

Dari tabel diatas menjelaskan bahwa hasil dari pengamatan peneliti pada saat layanan konseling kelompok terdapat perubahan dari setiap aspek yang diamati terkait dengan kompetensi intrapersonal.setiap pertemuaan, siswa mulai menunjukkan sikap percaya diri, mampu untuk memahami diri, menyadari kelemahan dan kelebihan, mampu membuat keputusan, mampu menghadapi kegagalan, disiplin diri, mampu mengendalikan diri, menghargai diri, dan menerima diri sebagai orang yang berharga.

Tahapan yang dilakukan dalam penelitian adalah sebagai berikut.

a. Tes Awal (Pretest)

Pre test dilaksanakan pada tanggal 06 Febuari 2016 dengan menyebar angket kompetensi intrapersonal yang terdiri dari 25 item pernyataan. Angket ini dibagikan kepada seluruh siswa kelas X yang berjumlah 118 orang. Kemudian dari 118 orang tersebut di ambil secara random cluster sampling 8 siswa kelas $\mathrm{X}$ yang dijadikan sample untuk diberikan layanan konseling kelompok.

b. Perlakuan (treatment)

Treatment diberikan dengan memberi layanan secara berkelanjutan menggunakan konseling kelompok dengan 4 tahapan yaitu tahap permulaan, tahap peralihan, tahap kegiatan dan tahap pengakhiran, [9]. Sesuai dengan jadwal yang disepakati peneliti dengan siswa yaithari Selasa kegiatan treatment dilaksanakan 3 kali pertemuan yaitu mulai 09 Febuari 2016, 13 Febuari 2016 dan tanggal 18 Febuari 2016. Layanan ini akan berhasil apabila siswa menunjukkan sikap memahami dirinya, mampu mengarahkan dirinya dan mampu menghargai dirinya.

c. Tes Akhir (posttest)

Post test dilaksanakan pada tanggal 20 Febuari 2016 kepada 8 siswa kelas $X$ disalah satu SMA Negeri di Kota Singkawang. pada kegiatan ini, peneliti membagikan angket kompetensi intrapersonal yang berjumlah 25 item. Peneliti kemudian mengolah hasil instrumen yang telah di isi siswa kemudian diolah menggunakan microsoft office excel 2007.

\section{Simpulan dan Saran}

Pelaksanaan konseling kelompok dilakukan melalui konseling kelompok dengan empat tahap dengan 3 kali pertemuan konseling.

Saran yang dapat diberikan kepada Guru BK agar bisa mengoptimalkan layanan-layanan BK khususnya layanan konseling kelompok untuk memperoleh berbagai kompetensi dan salah satunya kompetensi intrapersonal siswa.

Referensi

[1] Cavanagh, ME. 1982. The Counseling Experience : A Theoretical and Practical Approach. Monterey. California : Brooks/Cole Publishing Company.

[2] Erhamwilda. Jurnal Peningkatan Kompetensi Intrapersonal Siswa SMK melalui Model Konseling Sebaya MIMBAR, Vol. XXVII, No. 2 (Desember 2011): 173-182

[3] Furqon. (2011)

Statistika Penerapan Untuk Penelitian. Bandung: Alfabeta

[4] https://asrofulkhadafi.wordpress.com/2012/04/22/haki kat-konseling-kelompok/[di unduh 04 Januari 2016]

[5] Istirahayu, Iip dan Yusuf, Syamsu (2015). identification the quantity of student' the effectiveness of theistic spiritual counseling in improving student' intrapersonal competency". Global illuminators vol 2. (2015). (336-342).

[6] Natawidjaja. (2009). Konseling Kelompok, Konsep Dasar dan Pendekatan. Bandung: Risqi Press

[7] Prayitno. (2004). Layanan Bimbingan Kelompok dan Konseling Kelompok. Padang : Universitas Negeri Padang.

[8] Tohirin, (2007), “Bimbingan dan Konseling di Sekolah dan Madrasah (Berbasis Integrasi)” Jakarta: PT RajaGrafindo Persada.

[9] Wibowo, Mungin Eddy. (2005), Konseling Kelompok Perkembangan. Semarang: UNNES Press.

[10] Yusuf Gumelar (2014). Efektifitas Bimbingan Kelompok Untuk Meningkatkan Kompetensi Intrapersonal Siswa. Universitas Pendidikan Indonesia

[11] Yusuf, S. L.N. \& Nurihsan, A J. (2006). Landasan Bimbingan dan Konseling, Bandung: PT. Remaja Rosdakarya. 